\title{
PENERAPAN TEKNOLOGI KULTUR STARTER DAN GRAINS KEFIR UNTUK MENGHASILKAN MINUMAN SEHAT PADA KELOMPOK TANI TERNAK (KTT) MARGO MULYO BATURADEN
}

\author{
Triana Setyawardani, Mardiati Sulistyowati dan Juni Sumarmono \\ Fakultas Peternakan, Universitas Jenderal Soedirman Purwokerto \\ E-mail: trianaunsoed@gmail.com
}

\begin{abstract}
ABSTRAK. Program Pengabdian Kepada Masyarakat dengan judul Penerapan Teknologi Kultur Starter Dan Kefir Grains Untuk Menghasilkan Minuman Sehat di KTT Margo Mulyo Baturaden.dilaksanakan pada bulan Maret-Mei 2018, bertempat di desa Kemutug Lor, Kecamatan Baturaden, Jawa Tengah.Tujuan kegiatan adalah: (1) menghasilkan kefir sebagai minuman sehat, (2) menghasilkan es krim berbahan dasar susu kefir (3) untuk meningkatkan ketrampilan tentang cara mengolah susu menjadi produk kefir dan es krim kefir. Kegiatan diikuti oleh 15 peserta yang merupakan anggota kelompok KTT Margo Mulyo. Metode pengabdian dan tahapan yang dilakukan adalah ceramah, diskusi dan partisipasif (praktek pembuatan olahan). Hasil pengabdian yang dilakukan menunjukkan bahwa (1) peningkatan partisipasi pengetahuan sebesar 46,154\%, (2) peningkatan ketrampilan pembuatan es krim peserta sebesar $50.667 \%$, (3) dan peningkatan untuk mengolah minuman kefir sebesar $61,33 \%$. Kesimpulan dari kegiatan ini adalah kelompok KTT Margo Mulyo sudah melakukan pengolahan susu menjadi minuman kefir dan es krim berbahan dasar kefir.
\end{abstract}

Kata kunci: kefir; margo mulyo; es krim; susu

ABSTRACT. A Community Service Program entitled Technology Application for Starter Culture and Kefir Grains to Produce Healthy Drink in Margo Mulyo Farmer-Breeder Group (KTT) Baturraden was conducted from March to May 2019 in Kemutug Lor village, Batturaden, Central Java. The program aimed to (1) produce kefir as a healthy drink, (2) produce kefir milk-based ice cream, and (3) upskill milk processing into kefir and kefir ice cream. The program engaged fifteen female members of milk processing division in Margo Mulyo KTT undertook the program. The method and steps of the program included workshop, discussion, and participation (milk processing practice). The result of the program showed that (1) knowledge participation improved by 46.154\%, (2) upskill milk processing into kefir-based ice cream by 50,667\%, and (3) upskill processing kefir-based drink by 61,33\%. Conclusively, milk processing division in Margo Mulyo KTT had processed milk into kefir and kefir milk-based ice cream.

Keywords: kefir; margo mulyo; ice cream; milk

\section{PENDAHULUAN}

Kabupaten Banyumas merupakan salah satu sentra produksi susu sapi di Jawa Tengah. Wilayah dengan populasi sapi perah yang cukup banyak meliputi kecamatan Baturraden, Kedungbanteng dan Karanglewas. Keberadaan ternak sapi perah di kabupaten Banyumas diawali dengan pendirian Induk Taman Ternak pada awal tahun 60-an, dan kemudian berubah menjadi Balai Besar Pembibitan Ternak dan Hijauan Makanan Ternak (BPT-HMT). Pada tahun 2002 berubah menjadi Balai Besar Pengembangan Ternak Unggul Sapi Perah (BBPTU-SP) yang berlokasi di kecamatan Baturraden merupakan bukti bahwa sebagian wilayah Banyumas cocok bagi pengembangan ternak perah, khususnya sapi. Wilayah Baturraden berada pada ketinggian 650-700 $\mathrm{m}$ dpl dengan suhu udara harian antara $18-30^{\circ} \mathrm{C}$ dan kelembaban udara 70 - 80 \% (Badan Meteorologi, Banyumas)Total populasi sapi perah di kabupaten Banyumas kurang lebih 1500 ekor dengan produksi susu segar harian rata-rata 5500 liter. Sampai saat ini, sebagian besar (70\%) susu sapi yang diproduksi oleh peternak di kabupaten Banyumas dikirimkan ke Industri Pengolahan Susu (IPS) melalui gabungan koperasi peternak sapi perah Satria atau PESAT. Sebagian kecil diproses menjadi susu kemasan
MILBA (Milk Banyumas). Upaya pengolahan susu lebih dari sekedar dipasteurisasi belum dilakukan oleh peternak, maupun oleh masayarakat di kabupaten Banyumas. Peternak sapi perah di kabupaten Banyumas tergabung dalam kelompok-kelompok peternak, salah satunya adalah kelompok peternak KTT Margo Mulyo yang berlokasi di desa Kemutug Lor, kecamatan Baturraden. Beberapa permasalahan yang terkait dengan usaha persusuan di kabupaten Banyumas meliputi (1) produksi susu harian yang masih rendah, yaitu antara 10-12 liter/ekor/hari; (2) ketersediaan dan kualitas hijauan dan pakan terbatas; (3) pembiayaan tinggi; dan (4) teknologi preservasi dan pengolahan susu belum dilakukan.

Kelompok Tani Ternak (KTT) Margo Mulyo beralamatkan di desa Kemutug Lor, kecamatan Baturraden, Banyumas. Kelompok tersebut telah berdiri sejak tahun 1987 dengan bidang usaha peternakan sapi perah. KTT Margo Mulyo merupakan salah satu dari 14 KTT sejenis di kabupaten Banyumas, dan merupakan salah satu KPP yang paling dinamis. KTT Margo Mulyo memiliki anggota 18 kepala keluarga dengan total anggota kurang lebih 75 orang. Kelompok ini sudah berbadan hukum sejak Mulyo : 18 Desember 2015, No Badan Hukum AHU/00131380107 2015. Total jumlah sapi yang dipelihara sebanyak 97 ekor dan produksi susu 
segar rata-rata 350 liter/hari.Sebanyak 200 liter susu segar tiap hari disetorkan ke koperasi PESAT untuk selanjutnya dikirimkan ke industri pengolahan susu atau IPS.Selebihnya dipasarkan langsung ke konsumen dalam bentuk segar. Harga per liter susu segar ke koperasi adalah Rp. 4000, sedangkan jika dijual ke konsumen langsung sebesar Rp. 6000.

Usaha pengolahan susu secara rumah tangga telah dilakukan oleh beberapa anggota kelompok, yaitu dalam bentuk susu segar masak siap konsumsi, kerupuk dan caramel susu. Usaha tersebut dilakukan secara isidental untuk keperluan pameran atau bazar. Permasalahan yang ada pada produk kerupuk dan karamel belum bisa dijual secara komersial, karena produk tersebut harganya relatif mahal dan masyarakat belum terbiasa mengkonsumsi kerupuk susu dan karamel.

Berdasarkan survei pendahuluan yang dilakukan oleh tim, antusiasme anggota kelompok sangat besar untuk mengolah susu menjadi produk olahan yang mempunyai rasa enak dan dapat dijual/ dipasarkan. Hasil diskusi dengan ketua KTT Margo Mulyo menghasilkan kesepakatan dengan kelompok untuk mengolah susu menjadi produk es krim kefir dan kefir.Saat ini es krim kefir dan kefir merupakan produk yang banyak diminati dengan adanya Komunitas Kefir Indonesia dan pencinta es krim kefir, maka promosi dan pemasaran lebih mudah dilakukan. Kefir dapat dijual sebagai minuman fungsional yang menyehatkan dan dapat dijadikan pasta sebagai masker kefir. Manfaat kefir sebagai minuman sehat terbukti menurunkan diabetes, kolesterol, tekanan darah tinggi dan bisa digunakan untuk menurunkan berat badan.

Usahadilakukan dengantujuan memperpanjang masa simpan susu, dengan berbagai macam cara, antara lain adalah: (1) menyimpan susu pada cooling unit, (2) mengolah susu secepat mungkin menjadi produk olahan seperti susu pasteurisasi, UHT, atau produk lain seperti produk fermentasi (es krim kefir, kefir dan keju). Kefir merupakan produk fermentasi dapat dibuat dari susu sapi, kambing, kerbau, unta dan kedelai dengan penambahan biji kefir sebagai starter yang terdiri dari sejumlah bakteri asam laktat (BAL) dan yeast yang terikat dalam matriks polisakarida (O'Brien et al., 2016). Kefir merupakan produk fermentasi yang unik karena pada proses fermentasi laktosa menghasilkan asam laktat dan etanol. Kefir dihasilkan dari aktivitas mikroorganisme dalam biji kefir yang mengandung BAL dan yeast (GuzelSeydim et al., 2011; Satir and Guzel-Seydim, 2016).

Saat ini Tim PKM Laboratorium Teknologi Hasil Ternak Fakultas Peternakan lebih diarahkan pada pengembangan diversifikasi produk susu fermentasi, salah satunya adalah kefir.Produk ini mulai dikembangkan, karena selain termasuk dalam pangan fungsional, kajian untuk memperbaiki citarasa dan flavor kefir banyak dikerjakan.Kefir sebagai produk fermentasi susu dengan kultur starter berupa biji kefir atau kefir grains.Starter biji kefir terdiri dari bakteri asam laktat, dan yeast yang berperan menghasilkan asam laktat, karbondioksida, etanol, asetaldehid dan diasetil dan aseton untuk menghasilkan flavor dan aroma khas kefir (Beshkova et al., 2003). Kefir sebagai produk fermentasi mempunyai flavor dan sensasi khas, karena termasuk dalam minuman berkarbonasi yang mengandung vitamin $\mathrm{B}_{1}, \mathrm{~B}_{2}$, kalsium, asam amino dan vitamin $\mathrm{K}$ yang meningkat selama proses fermentasi. Umumnya mikroba yang terdapat dalam biji kefir akan menghasilkan asam laktat dan antibiotik yang berperan mencegah berkembangnya bakteri pembusuk dan bakteri patogen.

Tim pelaksana kegiatan PKM telah melakukan kegiatan pengabdian kepada masyarakat yang merupakan kegiatan wajib tercantum dalam salah satu butir pelaksanaan Tri Darma Perguruan Tinggi sebagai wujud interaksi antara tim pengabdi dari perguruan tinggi dengan masyarakat sebagai sarana alih teknologi hasil dari penelitian yang telah dilakukan oleh tim secara kontinyu dan berkesinambungan. Masyarakat peternak dalam hal ini kelompok KTT Margo Mulyo akan mampu meningkatkan produktivitasnya melalui pengolahan susu menjadi produk kefir dengan meningkatnya teknologi dalam bentuk ketrampilan dalam mengolah susu. Peningkatan produktivitas diikuti dengan peningkatan pendapatan anggota kelompok yang akan meningkatkan kesejahteraan anggota.

\section{METODE}

Metode untuk mendukung realisasi program adalah metode ceramah, diskusi dan partisipasif sehingga terjalin komunikasi aktif antara penyuluh dan partisipan dari kelompok tersebut. Kegiatan pelatihan diikuti oleh 15 orang istri peternak yang tergabung dalam KTT Margo Mulyo pada divisi bidang pengolahan susu. Kegiatan dilakukan dalam dua tahapan, yaitu meliputi (1) ceramah mengenai manfaat dan cara pembuatan kefir dengan menggunakan starter biji kefir dan starter komersial, diskusi apa kegunaan jangka panjang apabila usaha tersebut ditekuni dengan baik (2) memotivasi para ibu yang tergabung dalam kelompok untuk mulai melakukan kegiatan berwirausaha dibidang olahan susu terutama kefir dan sharing dengan peserta tentang motivasi untuk berusaha, supaya ibu-ibu bersemangat untuk mencoba dan membuat jajanan sehat dan (3) Melakukan praktek cara pembuatan es krim kefir dan minuman kefir.Keberhasilan pelaksanaan kegiatan dinilai dari pre dan post test kegiatan berupa materi 
dan praktek. Pre test dilakukan sebelum pelaksanaan kegiatan baik pada waktu sebelum diberikan teori maupun sebelum dilakukan praktek.

1. Ceramah dan Diskusi

Pemberian ceramah oleh tim pelaksana disertai dengan diskusi dimaksudkan memberikan gambaran secara teoritis kepada ibu-ibu peserta, pentingnya kita mengkonsumsi susu dan produk olahannya.Konsumsi susu terutama ditujukan pada anak-anak masa pertumbuhan untuk pertumbuhan tulang, gigi dan meningkatkan kecerdasan pada anak-anak.

2. Praktek Pembuatan Es krim kefir dan minuman kefir

Praktek pembuatan es krim dan minuman kefir dengan beberapa tahapan. Tahap pertama adalah pengenalan starter komersial kefir instan dan dari biji kefir. Tahap selanjutnya adalah pengenalan starter komersial yang dijual dalam bentuk bubuk dan dapat dibuat dengan cara lebih sederhana. Ibu-ibu peserta diberi beberapa alternatif pilihan untuk membuat kefir dan diharapkan dapat dilakukan di rumah dalam skala kecil pada awalnya dan bisa dilanjutkan untuk dijual guna menambah penghasilan keluarga.

3. Evaluasi

Teori/Pengetahuan dilakukan untuk mengetahui pengetahuan peserta penyuluhan.Evaluasi secara teori dilakukan dua kali yaitu sebelum dilakukan penyuluhan dan setelah dilakukan penyuluhan. Penyusunan soal-soal yang diberikan dibuat dengan cara mudah, dengan tujuan peserta mudah memahami soal tersebut. Peserta hanya melingkari jawaban yang dianggap benar oleh peserta, dan soal pretest yang diberikan adalah sama dengan post test. Kemampuan pengetahuan peserta dapat dilihat dan dihitung dari skor yang dihasilkan tersebut. Secara umum terjadi peningkatan pengetahuan dari peserta yang terlihat dari peningkatan nilai post testnya.

Evaluasi Praktek, dilakukan dengan tujuan untuk mengetahui ketrampilan peserta dalam (1) mempersiapkan alat dan bahan, (2) membuat starter dengan dua cara, (3) membuat es krim dan minuman kefir (4) mengemas produk kefir.

\section{HASIL DAN PEMBAHASAN}

Tim PKM berbasis risert telah melaksanakan kegiatan selama kurun waktu 3 bulan, dimulai dengan persiapan, resurvey dan komunikasi dengan ketua kelompok dengan anggota kelompok.

Kegiatan telah terealisasi $100 \%$, terdiri dari kegiatanberupapembekalankepadaanggotakelompok berupa pengetahuan/teori mengenai: manfaat susu bagi kesehatan, bagaimana cara memanaskan susu, kebersihan susu dan pemilihan susu yang akan digunakan sebagai bahan baku membuat es krim dan minuman kefir susu sapi.Kegiatan tersebut diikuti oleh 13 orang anggota kelompok Margo Mulyo yang bertempat di tempat ketua kelompok yaitu ibu Hajjah Soewarto selama kurang lebih 2-3 jam kegiatan.

Evaluasi kegiatan penyuluhan/teori

Tabel 1. Hasil evaluasi teori oleh tim PKM

\begin{tabular}{|c|c|c|c|c|c|}
\hline \multirow{2}{*}{ No. } & \multirow{2}{*}{ Nama } & \multicolumn{4}{|c|}{ Teori } \\
\hline & & pre & Post & Hasil & $\%$ \\
\hline 1 & Wiwit & 0,714 & 1,000 & 0,286 & 28,571 \\
\hline 2 & Siti Badriyah & 0,286 & 0,929 & 0,643 & 64,286 \\
\hline 3 & Sikem & 0,286 & 0,571 & 0,286 & 28,571 \\
\hline 4 & Supriyana & 0,286 & 0,786 & 0,500 & 50,000 \\
\hline 5 & Titi S & 0,214 & 0,786 & 0,571 & 57,143 \\
\hline 6 & Kusiyarti & 0,357 & 0,643 & 0,286 & 28,571 \\
\hline 7 & Tati & 0,214 & 1,000 & 0,786 & 78,571 \\
\hline 8 & Daisem & 0,643 & 0,786 & 0,143 & 14,286 \\
\hline 9 & Tati Sumiati & 0,429 & 0,857 & 0,429 & 42,857 \\
\hline 10 & Sunarti & 0,357 & 0,857 & 0,500 & 50,000 \\
\hline 11 & Sutarsih & 0,143 & 0,857 & 0,714 & 71,429 \\
\hline 12 & Warini & 0,286 & 1,000 & 0,714 & 71,429 \\
\hline 13 & Turyati & 0,500 & 0,643 & 0,143 & 14,286 \\
\hline
\end{tabular}

Hasil evaluasi pengetahuan anggota kelompok berupa teori tentang susu dan manfaatnya serta nilai gizi susu yang diikuti oleh 13 orang peserta mempunyai persentase kenaikan pengetahuan yaitu dengan kisaran 14,286 sampai dengan 78,571 \%, rataan secara umum adalah sebesar $46,154 \%$. Saat seseorang diberikan penyuluhan maka timbul pengetahuan tentang suatu rangsangan, kemudian timbul tanggapan dalam bentuk sikap terhadap rangsang yang diketahuinya. Setelah rangsangan diketahui dan disadari sepenuhnya, maka akan timbul tindakan terhadap rangsangan, tetapi dapat terjadi suatu rangsangan yang diterima langsung menimbulkan tindakan, tanpa dilandasi pengetahuan dan sikap terlebih dahulu (Tana dkk 2004).

Kenaikan pengetahuan dari anggota kelompok kurang dari 50 persen, hal ini disebabkan oleh beberapa faktor, antara lain : (1) kelompok sudah sering mendapatkan pengetahuan tentang susu dari instansi atau penyuluh lainnya; (2) kelompok juga merupakanbianaandaridepartemen perindustriandan Dikanak kabupaten Banyumas sehingga pengetahuan anggota sudah cukup bagus; (3) umumnya anggota mempunyai sapi perah dan pengetahuan sudah dipraktekkan dalam pemeliharaan/managemen pemerahan susu dengan baik. Peningkatan perilaku yang terjadi melalui penyuluhan, tidak dapat 
dilihat secara langsug. Hal ini dilatarbelakangi oleh beberapa hal yang dibutuhkan dalam merubah prilaku dengan beberapa tahapan yaitu tahapan mengetahui, tahapan berminat, tahapan penilaian, tahapan mencoba dan tahapan integrasi. Dari tim penyuluh juga berpengaruh terhadap keberhasilan penyuluhan yang tentukan oleh faktor penyuluh/ sumber daya manusia, materi yang diberikan, media penyuluhan yang digunakan dan kelompok sasaran yang menjadi obyek penyuluhan (Tana dkk, 2004).

Penyuluhan merupakan sarana untuk transfer pengetahuan yang bertujuan untuk merubah prilaku masyarakat, dimana merupakan suatu upaya untuk memberikan pengalaman belajar atau menciptakan kondisi bagi perorangan, kelomppok dan masyarakat yang mencakup peningkatan pengetahuan, sikap dan perilaku (Depkes RI 1997) Penyuluhan pada dasarnya merupakan proses komunikasi dan proses perubahan perilaku melalui pendidikan. Agar kegiatan penyuluhan dapat mencapai hasil yang maksimal, maka metode dan media penyuluhan perlu mendapat perhatian yang besar dan harus disesuaikan dengan sasaran yang dikehendaki (Pulungan, 2007).

Hasil menunjukkan terjadi penurunan ketidaktahuan. Hal tersebut memperlihatkan bahwa pengetahuan peserta penyuluhan meningkat setelah mengikuti kegiatan ini, baik yang berupa ceramah dan diskusi maupun praktek.Ketersedian materi kegiatan berupa teknologi tepat guna cara pembuatan es krim dan minuman kefir akan sangat membantu untuk menuntun peserta yang ingin melakukan praktek lagi di rumah masing-masing.

Hampir semua peserta pelatihan belum pernah membuat kefir, bahkan banyak juga yang belum pernah mengkonsumsi kefir. Pelatihan ini akan menjadi tepat sasaran pada kondisi yang berlaku seperti yang dilakukan saat ini. Peserta diharapkan mempunyai peningkatan pengetahuan pentingnya mengkonsumsisusudanprodukolahannya,disamping itu memotivasi para peserta untuk membuat kefir bagi keluarganya. Motivasi yang tercipta dari para peserta akan membantu untuk memasyarakatkan kefir, disamping itu memperkenalkan teknologi sederhana proses pembuatan kefir pada masyarakat. Disamping itumenciptakan peluang sangat besar bagi pengembangan pasar kefir serta bisa dikembangkan dalam skala rumah tangga.

Evaluasi kegiatan praktek pembuatan es krim kefir. Sesuai dengan rencana kegiatan PKM dilakukan evaluasi praktek untuk 2 produk yang diajarkan. Fungsi evaluasi dikerjakan adalah sebagai salah satu indikator keberhasilan program yang dilakukan oleh tim PKM. (tabel 2)

Hasil evaluasi praktek pembuatan es krim kefir diperoleh kenaikan persentase dari sebelum dilakukan praktek dibandingkan dengan setelah dilakukan praktek terjadi kenaikan $10-80 \%$ dengan rataan umumnya adalah 50,667 \%. Hasil evaluasi menunjukkan anggota yang dilatih membuat es krim sudah mengerti cara membuat dengan mudah.

Tabel 2. Hasil evaluasi pembuatan es krim

\begin{tabular}{llcccc}
\hline \multirow{2}{*}{ No. } & \multirow{2}{*}{ Nama } & \multicolumn{5}{c}{ Es Krim } \\
\cline { 3 - 6 } & pre & Post & Hasil & \% \\
\hline 1 & Wiwit & 0,5 & 1 & 0,5 & 50 \\
2 & Siti Badriyah & 0,4 & 1 & 0,6 & 60 \\
3 & Sikem & 0,2 & 0,9 & 0,7 & 70 \\
4 & Supriyana & 0,2 & 1 & 0,8 & 80 \\
5 & Titi S & 0,4 & 1 & 0,6 & 60 \\
6 & Kusiyarti & 0,6 & 1 & 0,4 & 40 \\
7 & Tati & 0,3 & 1 & 0,7 & 70 \\
8 & Daisem & 0,6 & 1 & 0,4 & 40 \\
9 & Tati Sumiati & 0,5 & 1 & 0,5 & 50 \\
10 & Sunarti & 0,5 & 0,9 & 0,4 & 40 \\
11 & Sutarsih & 0,9 & 1 & 0,1 & 10 \\
12 & Warini & 0,6 & 1 & 0,4 & 40 \\
13 & Turyati & 0,4 & 1 & 0,6 & 60 \\
14 & Rianti & 0,5 & 1 & 0,5 & 50 \\
15 & Darsem & 0,6 & 1 & 0,4 & 40 \\
\hline & & Rataan umum & & 50,667 \\
\hline
\end{tabular}

Evaluasi praktek penting dilakukan karena, fungsi dan peran evaluasi antara lain:

1. Sebagai indikator keberhasilan program yang dilaksanakan

2. Untuk seberapa besar masalah yang ada dikelompok sudah berhasil diatasi

3. Sebagai suatu bukti apakah rencana kegiatan sudah dilaksanakan sesuai tujuannya.

4. Sebagai salah satu tolak ukur keberhasilan metode penyuluhan berupa praktek yang telah dilaksanakan.

Evaluasi kegiatan dilakukan melalui pengumpulan dan menganalisa informasi secara sistemik dengan data yang diperoleh dari jawaban yang dihasilkan oleh anggota kelompok sebagai dasar acuan untuk kegiatan dan pengembangan selanjutnya. Tujuan evaluasi adalah untuk menentukan arah penyempurnaan kegiatan penyuluhan, memberikan gambaran kemajuan pencapaian tujuan, perbaikan program dan rencana kerja, mengukur efektifitas metode penyuluhan yang digunakan. Metode yang digunakan untuk pengumpulan data evaluasi adalah wawancara langsung menggunakan kue-sioner terstruktur untuk data kuantitatif dan atau menggunakan kuesioner terbuka untuk data kualitatif, angket (diisi oleh petani sendiri), observasi pengamatan langsung) untuk mengukur pembentukan kebiasaan atau keterampilan. 
Secara umum, pelaksanaan praktek yang diikuti oleh peserta dan antusiasme serta terjadinya interaksi yang intensif antara peserta dengan Tim Pelaksana. Praktek telah memberikan pengalaman nyata bagi peserta dalam membuat es krim berbahan dasar minuman kefir. Peserta dalam praktek pembuatan es krim diberikan pengetahuan tentang bagaimana cara mempersiapkan alat dan bagaimana membuat adonan es krim kefir supaya tepat dan menghasilkan produk yang sesuai keinginan. (tabel 3)

Selama proses pelaksanaan praktek yang dipimpin oleh Tim pelaksanaan dengan juga membuat demo cara pembuatannya, juga dilakukan evaluasi terhadap antusiasme, partisipasi dan keaktifan para peserta dalam mengikuti kegiatan tersebut. Secara umum, pelaksanaan praktek yang diikuti oleh peserta dan antusiasme serta terjadinya interaksi yang intensif antara peserta dengan Tim Pelaksana. Praktek telah memberikan pengalaman nyata bagi peserta dalam membuat kefir. Peserta dalam praktek pembuatan es krim kefir diberikan pengetahuan tentang bagaimana cara mempersiapkan alat dan bagaimana membuat adonan supaya tepat dan menghasilkan produk yang laku dijual.

Evaluasi kegiatan praktek pembuatan minuman kefir. Produk yang dipraktekkan oleh anggota kelompok selain es krim kefir, juga minuman kefir yang dibuat dalam dua kelompok, masing-masing terdiri dari 7-8 orang anggota. (tabel 4)

Evaluasi praktek dilakukan terhadap produk yang dibuat oleh peserta pelatihan. Hasil evaluasi menunjukkan terjadi peningkatan berkisar antara 20 sampai dengan $90 \%$ dengan rataan peningkatan secara umum adalah $61,33 \%$. Evaluasi dilakukan secara teori sebelum dilakukan praktek dan setelah dilakukan praktek. Evaluasi praktek dilakukan juga dengan melihat proses yang dilakukan oleh peserta. (tabel 5)

Tabel 4. Hasil evaluasi pelaksanaan praktek minuman kefir

\begin{tabular}{llcccc}
\hline \multirow{2}{*}{ No. } & \multirow{2}{*}{ Nama } & \multicolumn{4}{c}{ Minuman Kefir } \\
\cline { 3 - 6 } & Pre & Post & Hasil & $\mathbf{\%}$ \\
\hline 1 & Wiwit & 0,9 & 1 & 0,1 & 10 \\
2 & Siti Badriyah & 0,5 & 1 & 0,5 & 50 \\
3 & Sikem & 0,1 & 0,9 & 0,8 & 80 \\
4 & Supriyana & 0,2 & 1 & 0,8 & 80 \\
5 & Titi S & 0,1 & 1 & 0,9 & 90 \\
6 & Kusiyarti & 0,4 & 1 & 0,6 & 60 \\
7 & Tati & 0,3 & 1 & 0,7 & 70 \\
8 & Daisem & 0,3 & 1 & 0,7 & 70 \\
9 & Tati Sumiati & 0,2 & 1 & 0,8 & 80 \\
10 & Sunarti & 0,4 & 1 & 0,6 & 60 \\
11 & Sutarsih & 0,2 & 1 & 0,8 & 80 \\
12 & Warini & 0,8 & 1 & 0,2 & 20 \\
13 & Turyati & 0,6 & 1 & 0,4 & 40 \\
14 & Rianti & 0,4 & 1 & 0,6 & 60 \\
15 & Darsem & 0,3 & 1 & 0,7 & 70 \\
& Rataan & & & & 61,33 \\
\hline
\end{tabular}

Hasil evaluasi praktek untuk minuman kefir mempunyai nilai rataan lebih tinggi dibandingkan membuat es krim kefir (61,33 vs 50,667 \%). Hal ini menunjukkan bahwa peserta lebih tertarik dan lebih memahami tentang cara membuat minuman kefir dibandingkan membuat es krim kefir. Minuman kefir membuatnya lebih mudah dan alat yang digunakan lebih sederhana dan waktu lebih singkat dibandingkan membuat es krim.

Evaluasi penilaian produk secara sensori. Sesuai rencana yang diusulkan dalam kegiatan PKM, produk yang dihasilkan oleh peserta, diuji

Tabel 3. Hasil evaluasi praktek pembuatan es krim kefir para peserta pelatihan

\begin{tabular}{|c|c|c|}
\hline No. & Aspek & Evaluasi \\
\hline 1. & Persiapan alat dan bahan & $\begin{array}{l}\text { Secara umum peserta dapat mempersiapkan alat dan bahan untuk membuat es } \\
\text { krim dengan baik. }\end{array}$ \\
\hline 2. & $\begin{array}{l}\text { Membuat starter berupa grans kefir instan dan dari biji } \\
\text { kefir }\end{array}$ & $\begin{array}{l}\text { Peserta aktif mencoba mempraktekkan teknik kultur menggunakan starter } \\
\text { komersial yang ada sesuai dengan yang dicontohkan oleh Tim dan mencoba } \\
\text { membuat starter dengan menggunakan kultur murni dengan melihat peragaan dari } \\
\text { Tim pelaksana. }\end{array}$ \\
\hline 3. & Tahapan pembuatan es krim & $\begin{array}{l}\text { Kefir dibuat dengan tahapan awal yaitu pasteurisasi susu kambing. } \\
\text { Umumnya peserta sudah terbiasa merebus susu dengan baik sesuai dengan } \\
\text { prosedur dan petunjuk dari Tim Peserta sudah mendapatkan pengetahuan } \\
\text { baru tentang proses pasteurisasi susu dengan benar. }\end{array}$ \\
\hline 4. & Penambahan starter berupa grains kefir & $\begin{array}{l}\text { Peserta mampu menambahkan starter grains kefir dalam pembuatan kefir } \\
\text { dan bisa menghitung kebutuhan starter untuk } 1 \text { liter susu kambing. Peserta } \\
\text { juga sudah mampu membuat starter yang berasal dari kultur komersial dan } \\
\text { menghitung kebutuhan penggunaannya untuk } 1 \text { liter susu. }\end{array}$ \\
\hline 5. & Membuat adonan es krim kefir & $\begin{array}{l}\text { Kefir yang sudah jadi dibuat menjadi adonan es krim dengan } \\
\text { penambahan bahan emulsi dan pelembut es krim. }\end{array}$ \\
\hline 6. & Melakukan pembekuan dan mixing pada adonan & $\begin{array}{l}\text { Peserta telah melakukan pembekuan pada adonan dan freezer kemudian } \\
\text { dilakukan mixing untuk membuat adonan menjadi homogen. }\end{array}$ \\
\hline 7. & Mengemas es krim kefir & $\begin{array}{l}\text { Peserta mengemas es krim dalam kemasan cup } 60 \mathrm{ml} \text { kemudian } \\
\text { membekukan kembali. Kemasan cup terdiri dari dua macam yaitu cup } \\
\text { platik dan cup kertas }\end{array}$ \\
\hline
\end{tabular}


Tabel 5. Evaluasi praktek membuat minuman kefir yang dilakukan oleh peserta

\begin{tabular}{|c|c|c|}
\hline No. & Aspek & Evaluasi \\
\hline 1. & Persiapan alat dan bahan & $\begin{array}{l}\text { Secara umum peserta dapat mempersiapkan alat dan bahan untuk } \\
\text { membuat minuman kefir dengan baik. }\end{array}$ \\
\hline 2. & $\begin{array}{l}\text { Membuat starter berupa grans kefir instan dan dari biji } \\
\text { kefir }\end{array}$ & Peserta aktif mencoba peremajaan biji kefir dengan menggunakan susu. \\
\hline 3. & Tahapan pembuatan minuman kefir & $\begin{array}{l}\text { Kefir dibuat dengan tahapan awal yaitu pasteurisasi susu. Umumnya } \\
\text { peserta sudah terbiasa merebus susu dengan baik sesuai dengan prosedur } \\
\text { dan petunjuk dari Tim } \\
\text { Peserta sudah mendapatkan pengetahuan baru tentang proses pasteurisasi } \\
\text { susu dengan benar. }\end{array}$ \\
\hline 4. & Penambahan starter berupa grains kefir & $\begin{array}{l}\text { Peserta mampu menambahkan starter grains kefir dalam pembuatan kefir } \\
\text { dan bisa menghitung kebutuhan starter untuk } 1 \text { liter susu sekitar } 5 \% \text {. } \\
\text { Peserta juga sudah mampu membuat starter komersial. }\end{array}$ \\
\hline 5. & Melakukan inkubasi & $\begin{array}{l}\text { Susu yang diberi starter kemudian diinkubasi pada suhu kamar selama } \\
16-24 \text { jam. Peserta bisa mengatur waktu inkubasi untuk mendapatkan } \\
\text { rasa asam sesuai dengan yang dikehendaki. Inkubasi untuk fermentasi } \\
\text { kefir dilakukan pada suhu kamar, }\end{array}$ \\
\hline 6. & Melakukan penyaringan & $\begin{array}{l}\text { Peserta telah melakukan penyaringan pada hasil fermentasi kefir untuk } \\
\text { memisahkan antara biji dan cairan minuman. pada adonan dan freezer } \\
\text { kemudian dilakukan mixing untuk membuat adonan menjadi homogen. }\end{array}$ \\
\hline 7. & Mengemas minuman kefir & Peserta mengemas minuman kefir dengan kemasan botol dan cup plastik. \\
\hline
\end{tabular}

komersialisasi produk sebelum dipasarkan. Salah satu cara pengujian produk dilakukan oleh panelis semi terlatih yang diambil dari mahasiswa/i. Persyaratan sebagai panelis telah dilaksanakan sebelum melakukan pengujian produk. Beberapa persyaratan yang harus dipenuhi, antara lain : (1) panelis sudah mendapatkan pengetahuan dan caracara pengujian produk; (2) panelis terdiri dari wanita dan pria; (3) panelis tidak dalam keadaan sakit; (3) panelis tidak mempunyai kebiasaan merokok jika laki-laki.

Hasil pengujian sensori pada produk minuman kefir, rataan tertinggi pada atribut rasa yaitu 3,45 pada minuman kefir yang dibuat dari biji kefir yang tidak manis atau tidak diberi gula. Untuk atribut bau kefir terdapat dua produk yang mempunyai nilai rataan sama yaitu pada minuman kefir yang dibuat dari biji kefir dan asam dan minuman kefir yang dibuat dari starter komersial (instan) yaitu dengan skor 2,3. Analisis sensori pada dasarnya bersifat objektif dan subjektif. Analisis objektif ingin menjawab pertanyaan dasar dalam penilaian kualitas suatu produk, yaitu pembedaan dan deskripsi, sementara subjektif berkaitan dengan kesukaan atau penerimaan. Adapun tujuan analisis sensori adalah untuk mengetahui respon atau kesan yang diperoleh pancaindra manusia terhadap suatu rangsangan yang ditimbulkan oleh suatu produk (Setyaningsih dkk., 2010).

Kefir mempunyai tekstur hampir sama dengan yogurt dan relatif lebih kental daripada yogurt. Hasil penilaian oleh 20 panelis diperoleh rataan terbesar untuk atribut tekstur kefir adalah pada kefir yang dibuat dari starter biji kefir dan rasa manis dengan kode 119 dengan skor penilaian 3,6 dengan kriteria penilaian tekstur tidak kasar sampai dengan halus $(3-4)$ atau dapat digolongkan dengan tekstur yang halus. Untuk atribut kesukaan produk, panelis menilai kefir yang diujikan yang paling disukai adalah kefir dengan kode 119 atau kefir yang dibuat dari starter biji kefir dan mempunyai rasa manis.

\section{SIMPULAN}

Kegiatan PKM berbasis riset yang telah dilakukan oleh tim di kelompok peternak sapi perah Margo Mulyo yang berlokasi di Kemutug Lor, Banyumas, dapat disimpulkan sebagai berikut:

1. Terjadi peningkatan pengetahuan anggota kelompok setelah diberikan penyuluhan secara teoritis dengan kenaikan sebesar 46, $154 \%$.

2. Peningkatan ketrampilan membuat es krim kefir dengan peningkatan sebesar 50,667 \%.

3. Peningkatan ketrampilan membuat minuman kefir oleh peserta penyuluhan sebesar $61,33 \%$.

4. Kegiatan praktek mempunyai peningkatan lebih besar dibandingkan pemberian penyuluhan secara teoritis ( 46,154 vs 50,667 dan 61,33 )\%.

5. Produk minuman kefir baik yang dibuat dari biji kefir maupun starter komersial keduanya disukai oleh panelis.

6. Secara umum kegiatan PKM ini dinilai oleh peserta mempunyai skor 3 dan 4 yaitu kisaran baik dan sangat baik.

\section{DAFTAR PUSTAKA}

Beshkova, D., E. Simova, G. Frengova, Z. Simov, dan Z. P. Dimitrov. 2003. Production of volatile aroma compounds by kefir starter cultures. Int. Dairy J 13: 529-535.

Guzel-Seydim, Z. B., T. Kok-Tas, A. K. Greene, dan A. C. Seydim. 2011. Review: Functional Properties of Kefir, . Food. Sci and Nut. 51: 261-268. 
O’Brien, K. V., K. J. Aryana, W. Prinyawiwatkul, K. M. C. Ordonez, dan C. A. Boeneke. 2016. Short communication: The effects of frozen storage on the survival of probiotic microorganisms found in traditionally and commercially manufactured kefir. J.Dairy. Sci. 99: 7043-7048.

Pulungan, 2008. Pengaruh metode penyuluhan terhadap peningkatan pengetahuan dan sikap dokter kecil dalam pembrantasan sarang nyamuk demam berdarah (PSN-DBD) di
Kecamatan Helvetia 2007. Thesis Universitas Sumatera Utara, Medan.

Satir, G., dan Z. B. Guzel-Seydim. 2016. How kefir fermentation can affect product composition? Small Rumin. Res. 134: 1-7.

Tana, Delima dan W. Riyadini. 2009. Evaluasi Model Penyuluhan Dalam Peningkatan Pengetahuan,Sikap Dan Praktek Mengenai Sindrom Terowongan Karpal Pada Pekerja Beberapaperusahaan Carmen Di Jakarta, Tahun 2004. Media Penelit dan Pengembang Kesehatan $3:$ 109-115. 